\title{
Carbon Footprint of Beef Cattle in a Conventional Production System: a Case Study of a Large-Area Farming Enterprise in the Wielkopolska Region
}

\begin{abstract}
Animal production is a significant source of greenhouse gas (GHG) emissions. One of the major challenges in sustainable management is to mitigate the effects of climate change by reducing GHG emissions. The diversity of animal production systems and accompanying diversification of technological processes, mean that specific production effects can be obtained at different levels of GHG emissions. The aim of the study was to determine the carbon footprint (CF) of beef cattle grown in a conventional system (i.e. indoor confinement). The research was carried out on the beef cattle farm belonging to a large-area enterprise, Długie Stare Ltd. The beef cattle production system consisted of the following subsystems: a basic breeding herd (consisting of suckler cows, replacement heifers and calves up to 6.5 months), breeding heifers, breeding bulls and fattening bulls. The method of life cycle analysis (LCA) in the stages from "cradle-to-farmgate" was used to assess the GHG emissions associated with the production of beef cattle. The average $\mathrm{CF}$ in the entire beef cattle production system was $25.43 \mathrm{~kg}$ of $\mathrm{CO}_{2} \mathrm{~kg}^{-1}$ of live weight of marketed cattle, while in the individual subsystems of basic breeding herd, breeding heifers, breeding bulls and fattening bulls, the CF (after GHG allocation) was: $11.0 \mathrm{~kg} \mathrm{CO}$ eq., $34.30 \mathrm{~kg} \mathrm{CO}_{2}$ eq., 27.32 and $25.40 \mathrm{~kg} \mathrm{CO}_{2}$ eq., respectively. GHG emissions associated with young calves staying in the cow-calf pairs until weaning (in the period from 0-6.5 months), had a decisive influence on the final CF in each of the subsystems of beef cattle production. The second important factor directly affecting the CF was GHG emissions related to methane $\left(\mathrm{CH}_{4}\right)$ enteric fermentation and manure management. Knowledge of factors affecting the $\mathrm{CF}$ structure allows better identification of critical areas in production processes with high GHG emission potential. Information on the CF of beef cattle and beef meat responds to a wider societal demand for the ecological characteristics of market products, which ultimately contributes to improving their market competitiveness.
\end{abstract}

Key words: carbon footprint, beef production, emission of greenhouse gases, life cycle assessment, agriculture

JEL Classification: Q54, Q57

\section{Introduction}

Expanding beef markets in the world have contributed to the development of exports in many countries. In Poland, as in South American countries, there was an increase both in the volume of production and exports due to improved accessibility to the beef market in the EU. In Poland, beef meat exports increased from approximately 90 thousand tons in the years 2004-2005 up to approximately 281 thousand tons in 2013. The proportion of exports in beef production reached close to $43 \%$ (FAOSTAT, 2018). An important factor for the further development of local beef production has become the competitiveness of Polish beef meat in European markets. In Poland, there are relatively few high-quality beef meats

${ }^{1}$ dr hab., prof. IŚRL PAN, Department of Agricultural Production Systems IAFE, Bukowska 19 Str., 60-809 Poznań, e-mail: jerzy.bienkowski@isrl.poznan.pl 
obtained from the beef cattle breeds. Since Poland's entry into the EU, the proportion of beef cows in relation to dairy cows has been steadily increasing, reaching a level of more than $8 \%$ in 2016 years. Beef production is still based on a large proportion of cattle used for milk production (GUS, 2018).

At present, the quality meat program (QMP) and the Union scale for the classification of carcasses are used to support the production of high-quality beef (Polish Beef Association, 2018; Regulation..., 2013). These measures are not sufficient for the competitive development of beef cattle production. The requirements of sustainable development and climate protection are a new challenge for the Polish beef sector. Global interest in environmental problems is confirmed by the government policies of many economically developed countries and by the requirements of consumers who demand preparation of verifiable and reliable information on the extent of the environmental impacts associated with products being purchased. The common task of these activities is to motivate producers to create environmental characteristics of products. Examples of such activities include the development of environmental information in the form of documents defining the product's carbon footprint (CF), such as the Climate Certificate, or describing the environmental profile referring to a wide range of environmental effects, known as Environmental Product Declaration (EPD, 2018).

Studies on the effects of climate change indicate that the main threat to economic development and the state of the environment in the world are high levels of GHG emissions linked to the growth of the global economy, the use of energy from fossil fuels and intensive agricultural production. It is estimated that animal production accounts for 14.5 to $18 \%$ of global anthropogenic GHG emissions (Steinfeld et al., 2006; Gerber et al., 2013). Currently, GHG emission control is treated as an important instrument supporting environmental management in agricultural production aimed at mitigating the effects of climate change. The carbon footprint method is increasingly used to assess GHG emissions associated with economic processes. It is identified with global warming and is defined as the balance of GHG emissions throughout the product life cycle (Wiedmann and Minx, 2007). The most important principles and guidelines for the calculation of the carbon footprint of products and services are outlined in the British Technical Specification PAS2050:2011 (BSI, 2011). The most up-to-date specification of the carbon footprint methodology was recently developed by the International Organisation for Standardization (ISO, 2013). The significance of the carbon footprint results from the disclosure of the relationship between GHG emissions, global warming and climate change.

In animal production, the main sources of GHG emissions are processes: feed production, enteric fermentation in animals during digestion (mainly in ruminants), storage of manure and energy consumption in farm buildings, and feed preparation (Vergé et al., 2007). The sources of $\mathrm{CO}_{2}$ emissions in agriculture are fuel combustion (diesel oil, gasoline), production of thermal energy (because of burning fuel oil, gas, coal) and the use of electricity. $\mathrm{CH}_{4}$ is produced during enteric fermentation and during storage of manure or slurry. $\mathrm{CH}_{4}$ emissions from enteric fermentation and from manure constitute respectively $88.3 \%$ and $11.5 \%$ of its total emissions in agriculture (GUS, 2017). $\mathrm{CH}_{4}$ emission levels in ruminants have a major impact on the carbon footprint of beef and milk. Significant amounts of nitrous oxide $\left(\mathrm{N}_{2} \mathrm{O}\right)$ are emitted due to the use of manure and mineral nitrogen fertilizers. The production of fodder is associated with GHG emissions from fuels burned during field works, preparation and transport of concentrated feeds, production of mineral fertilizers and emissions associated with the use of fertilizers in fields. The use of nitrogen 
fertilizers, crop residues and manure contribute to the increase of $\mathrm{N}_{2} \mathrm{O}$ emissions in the nitrification processes. This gas has 298 times higher warming potential than $\mathrm{CO}_{2}$ in a 100 year period. For comparison, $\mathrm{CH}_{4}$ has a warming potential that is 25 times higher than $\mathrm{CO}_{2}$ (BSI 2011). The use of organic soils or loss of forest land for the purposes of animal grazing or cultivation causes large amounts of $\mathrm{CO}_{2}$ to be released into the atmosphere. GHG emissions from the use of electricity and fuels in livestock buildings and during feed preparation contribute relatively little to GHG emissions (Huijbregts et al., 2010).

Breeding systems for beef cattle differ in terms of many parameters, such as the age that animals are slaughtered, the maintenance of animals in buildings, grazing duration or the type of fodder. According to Nguyen'a et al. (2010) the rearing of cattle for slaughter of beef breeds (slaughtering at the age of 16 months) is characterized by the highest Global Warming Potential (GWP) per kg of slaughter weight, while the lowest GWP values occur in the system of maintaining bull calves (from dairy cows) in stalls, which are fed with concentrated feeds and slaughtered at the age of 12 months. Ruminants have a lower coefficient of conversion of feed to meat compared to pigs and poultry, which means that more feed per kg of body weight gain is consumed. This is also reflected in higher GHG emissions per kg of body weight.

The prerequisite for maintaining the competitiveness of Polish beef on global food markets is the introduction of practices promoting sustainable methods of production which are conducive to the reduction of environmental impacts. Currently, the environmental standards of production and the environmental impact of products are, both in Europe and in the world, one of the most important issues focusing on product quality. At present, the beef production sector has no resources or implemented systems to provide information on the assessment of the carbon footprint of meat. This creates an important information gap and, on the other hand, indicates the existing possibilities of improving both financial effects and environmental characteristics of beef. Environmental policies of many countries around the world, including within the EU, are aiming at a gradual reduction of environmental footprints in production processes on farms and in the food industry. An important part of these efforts is the development of low-emission agricultural production technologies and systems for their certification.

The aim of the study was to determine the GHG emissions of beef cattle reared in the conventional housing on a large-scale farms and to determine the carbon footprint of bulls for slaughter and heifers for breeding. The practical effect of the research is the possibility of linking a specific production system with the formation of carbon footprint at various stages of the beef cattle production.

\section{Materials and methods}

The research was carried out in the agricultural enterprise Dlugie Stare Sp. z o.o. (currently owned by the National Center for Agricultural Support) in 2015-2016. The company manages an area of 3240 ha, including 3120 ha of agricultural land. It is among a narrow group of agricultural enterprises owned by the State Treasury responsible for the implementation and dissemination of technological progress in agriculture. It specializes mainly in the production of milk with high quality parameters and beef cattle. The farm has 4 free stall facilities for dairy cows. On average, the company has 2,000 Holstein-Friesian (HF) cattle, including 900 milk cows. The company owns a beef cattle farm at the Gołanice 
village. There are 3 stalls on this farm. Two of them are loose housing with an outdoor yard, and one is an open-sided stall with a roof over the cattle bedding area and a feed table. On the farm in Golanice, there are 473 beef cattle with 200 suckler cows, including 90 pure-bred Limousine and 110 cows which are crossbreeds between HF and Limousine. Trying to improve the quality of beef cattle, a grading crossing of crossbred cows with Limousine bulls has been used for several generations. Thanks to that, crossbred cows comprise over $75 \%$ of the beef cattle breed. The cow replacement rate is around 0.166 . Pregnancy rate at herd level is around 95\%. Inter-calving interval varies between 365 and 375 days. There are two calving periods within the year, i.e. April-May and July-October. The calves stay with their mothers for about 6.5 months. After this period, they are weaned - reaching by then an average weight of $220 \mathrm{~kg}$. About $30 \%$ of Limousine bull calves are further raised for breeding purposes. The rearing of bulls is conducted until the age of about 27 months (690-700 kg of weight), and after that period the bulls undergo assessment with respect to their prospective breeding value as they are intended for sale as breeding bulls. Fattening of bull calves is conducted on another facility located in the Święciechowa farm establishment. At the age of 20-22 months, they are directed to sales when they gain a body weight of around $700 \mathrm{~kg}$. All heifers are left for further rearing. They start the breeding program at the approximate age of 22 months (weighting about $500 \mathrm{~kg}$ at that time), while heifers which failed to conceive are sold for slaughter. On average, 34 heifers are required for replacement each year. The rest of the pregnant heifers, which are not included into the replacement stock, are sold as breeding heifers (about 28 months old). In addition to animal husbandry, the farm has also a well-developed plant production branch. Its primary purpose is to provide the animal feed. The production of cash crops (cereals, winter rape and sugar beet) is an important complement to the company's revenue. Animals are kept loose in buildings, on a deep litter, and have access to an outdoor yard all year long. The straw bedding is replenished 2-3 times a week. Manure is removed from the stalls on average every 2-3 months, depending on the frequency of straw addition. It is stored in large piles on the farmland and spread in the spring and fall.

The carbon footprint analysis was conducted in accordance with the methodology of Life Cycle Analysis (LCA), which included the steps from 'cradle-to-farm-gate'. The carbon footprint is a concept used in the assessment of GHG emissions and in the public discussion on the actions needed to reduce the risks associated with climate change. In general terms, it means gaseous emissions of compounds that contribute to the intensification of the greenhouse effect throughout the production and consumption cycle of products. CF is expressed in the form of the sum of the greenhouse effect product for the substances and mass of their emissions. It includes both direct and indirect emissions that arise throughout the product's life cycle. Usually, in the agricultural studies it is presented in the form of quantitative indicators: (a) as the total $\mathrm{GHG}$ emission in $\mathrm{kg}$ of $\mathrm{CO}_{2}$ equivalent per unit of area per year, (b) as a $\mathrm{GHG}$ emission in $\mathrm{kg}$ of $\mathrm{CO}_{2}$ equivalent per $\mathrm{kg}$ of product.

According to procedure, the system boundary had to be defined at the start of the study. Processes related directly to the production activities on the farm (i.e. beef cattle breeding, cultivation of crops used in cattle feeding, production of concentrate mixtures, animal feeding, manure management and storage) were placed inside the system boundaries. Within the system, there are also indirect processes from the manufacturing industry related to the production of raw materials and products used as inputs in the farm's production activity. The basic functional unit (FU) was $1 \mathrm{~kg}$ live weight (LW) of beef cattle (Figure 1). As a basis for the distribution of the GHG emission flow between the co- 
products, which were exported outside the system, the economic allocation principle was applied. The raw materials and consumables used in these processes were also subject to the economic allocation and applied using this same allocation coefficient.

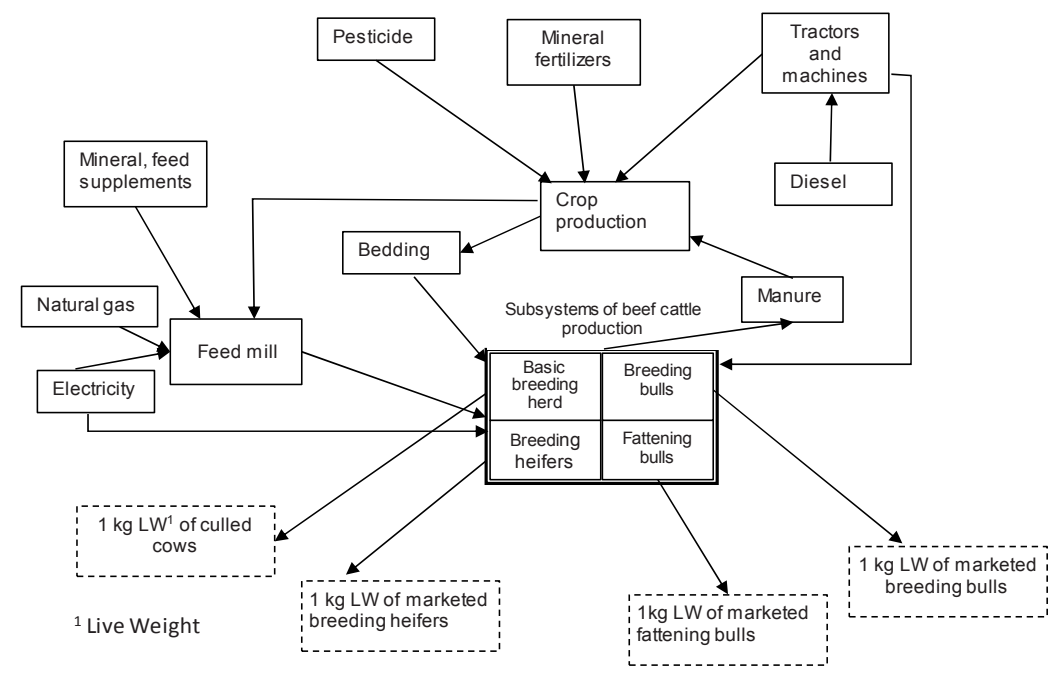

Fig. 1. Description of the beef cattle production system for the carbon footprint investigated in the analyzed farm Source: Authors' own description.

Following the description of the production system, the second step in the LCA analysis was to develop the inventory table. It presents a quantitative summary of the resources used, means of production, and emissions released into the environment that are associated with the functioning of different processes within the system and referenced to the functional unit. The estimated total amount of GHG emission in the production of beef cattle at the farm level consists both of direct and indirect emissions. Sources of direct emission were enteric fermentation of cattle, manure in stalls, storage of manure on piles or slurry in tanks and subsequent application of manure and slurry on arable fields. Methane $\left(\mathrm{CH}_{4}\right)$ emission derived from enteric fermentation was estimated based on a model that was related the function dependency between the forage dry matter intake and the emission volume of $\mathrm{CH}_{4}(\mathrm{IPCC} 2006)$. Estimation of $\mathrm{CH}_{4}$ emissions from cattle faeces was based on a model that uses data on the types of manure management, methane conversion factor, methane producing capacity for manure and volatile solid excreted for each cattle class (IPCC 2006). To estimate direct $\mathrm{N}_{2} \mathrm{O}$ emissions, the new algorithm presented in the EEA (2013) was used. Indirect $\mathrm{N}_{2} \mathrm{O}$ emissions related to cattle were also included. They originally stem from the gaseous losses of nitrogen compounds in the ammonia $\left(\mathrm{NH}_{3}\right)$ and $\mathrm{NO}_{\mathrm{x}}$ forms (in fact as a result of their deposition and subsequent biochemical transformations in soils).

According to literature, the most nitrogen gas losses come from the volatilization of $\mathrm{NH}_{3}$ in stalls and during manure storage. Another place of $\mathrm{N}$ gas losses in the form of $\mathrm{N}_{2} \mathrm{O}$ and $\mathrm{NH}_{3}$ is the application of manure (and mineral fertilizers) on the field. Data relating to the GHG emissions associated with industrial-manufacturing processes (off-farm) of mineral fertilizers, chemical plant protection products, electricity, fossil fuels and transport 
were taken from the Ecoinvent database (2018). The SimaPro 8.5 program was used for the calculation of the CF of the functional units (PRÉ Consultants, 2018). The feeding of animals with roughage and grain, required also that emissions related to the cultivation, harvesting of plants and their transport be taken into account. Detailed descriptions of calculating the GHG emissions in crop production in the analyzed farm were presented in the papers by Holka et al. (2016) and Bieńkowski et al. (2017). All concentrate mixtures used in cattle feeding were produced in a compound feed plant owned by the company. A precondition for the calculation of the GHG emissions ascribed to these concentrate mixtures was detailed information on the ingredient composition, i.e. quantitative composition and the local production processes of the concentrate ingredients (cereals, winter rape) in the former stage of field cultivation.

In the case of components being byproducts of the food industry (rape seed meal, cereal bran, beetroot pulp), it was necessary to widen the scope of the concentrate production system by the inclusion of upstream processes embracing the crop cultivation followed by crushing and milling together with crop transport to processing plants. The primary data source for the subsystem of the processing industry using crop feedstocks, were inventory data of the crop cultivation in the analyzed enterprise. Besides this, another two types of data were needed to estimate emissions associated with production activity in the processing plants. The first type of data required was mainly information on the consumption of electricity, natural gas and diesel in $\mathrm{kWh}$ per ton of the main product (Marinussen et al., 2012a; Marinussen et al., 2012b). The second type was GHG emissions factors for each type of fuel corresponding with its energy value (IPCC 2006). In view of the fact that there are multiple effects of these processes (meaning that apart from the main product, there is yet one or more byproducts of commercial value) it was required to carry out the partition of all emissions and material inputs between the main product and the byproducts. Economic allocation was chosen as the way of proportional distribution of environmental burdens between products.

Within the beef cattle production system on the farm, there were several integrally connected subsystems. After identification of cattle groups and defining different types of activities linked to these groups as separate unit processes, four subsystems of cattle production were identified: basic breeding herd, breeding heifers, breeding bulls and fattening bulls. Number of cattle, the length of stay and the final body weight in a given group are shown in Table 1. In each subsystem, inputs flow into and outputs flow out of the unit processes were referenced to the functional unit of $1 \mathrm{~kg}$ of marketing livestock.

Table 1. Number of beef cattle and production level of marketed animals for different beef cattle production subsystems

\begin{tabular}{l|rrrr}
\hline \multicolumn{1}{c|}{ Item } & \multicolumn{4}{c}{ Beef cattle production subsystem } \\
& Cow-calf & Breeding heifer & Breeding bulls & Fattening bulls \\
\hline $\begin{array}{l}\text { No. of basic breeding unit }{ }^{1} \text { (BBU) } \\
\text { No. of young beef cattle in animal- }\end{array}$ & 200 & - & - & - \\
year & - & 111.4 & 19.4 & 99.6 \\
No. of animals for market per year & 32.8 & 62.2 & 12.6 & 82.4 \\
Final body weight, kg & 663.0 & 538.3 & 698.0 & 696.8 \\
Quantity of sold products per year, & 21746.4 & 33476.0 & 8794.8 & 57416.3 \\
kg & 1 kg LW ${ }^{2}$ of & 1 kg LW of & 1 kg LW of & $1 \mathrm{~kg} \mathrm{LW} \mathrm{of}$ \\
Functional unit (FU) & cull beef cow & breeding heifer & breeding bull & fattening bull \\
\hline
\end{tabular}




\section{Results and Discussion}

A comprehensive inventory database of the beef cattle production process is presented in Table 2. In view of the presence of the diverse breeding scheme within the cattle herd, data on the inputs from the technosphere (raw materials, industrial materials, energy) and emissions of GHG had to take into account the different production activities within the whole system (Table 2).

Table 2. Inventory data of inputs and emissions per $1 \mathrm{~kg} \mathrm{LW}$ of marketed animals for different subsystems of beef cattle production

\begin{tabular}{l|rrrrr}
\hline \multicolumn{1}{c|}{ Item } & Cow-calf & $\begin{array}{c}\text { Breeding } \\
\text { heifer }\end{array}$ & $\begin{array}{c}\text { Breeding } \\
\text { bull }\end{array}$ & $\begin{array}{c}\text { Fattening } \\
\text { bull }\end{array}$ & $\begin{array}{c}\text { Whole } \\
\text { system }\end{array}$ \\
\hline Roughage, kg DM & 54.86 & 9.36 & 7.31 & 6.81 & 51.69 \\
Cereals, Concentrated feed, kg DM & 1.12 & 0.78 & 1.48 & 0.52 & 0.88 \\
Bedding, kg & 19.52 & 3.45 & 2.72 & 3.38 & 6.24 \\
Electricity, kWh & 0.87 & 0.15 & 0.12 & 0.11 & 0.26 \\
Fuel, kg & 0.34 & 0.05 & 0.05 & 0.04 & 0.10 \\
Tractors and machines, kg & 0.03 & 0.01 & $<0.01$ & 0.01 & 0.01 \\
Emissions from animals and manure: & & & & 225.23 & 484.00 \\
$\mathrm{CH}_{4}$ emission, g & 1608.79 & 260.97 & 241.40 & 22.01 \\
$\mathrm{~N}_{2} \mathrm{O}$ emission, g & 80.91 & 11.75 & 10.07 & 7.52 & 22.01 \\
$\mathrm{CO}_{2}$ emission, g & 1033.65 & 194.99 & 143.89 & 135.21 & 313.20 \\
\hline
\end{tabular}

Source: Authors' own calculations.

Data presented in the inventory table is the result of aggregating the different types of environmental interventions (consumption of materials and energy as well as GHG emissions) in many unit processes, which are then referred to each product's reference flow. Each of the four groups of animals had a separate production characteristic and differed in the type of product, which was reflected by four different functional units. The overall consumption of roughage per $1 \mathrm{~kg} \mathrm{LW}$ of cattle for sale was $51.69 \mathrm{~kg}$. A high, comparable level of feed consumption per $1 \mathrm{~kg} \mathrm{LW}$ of culled cow occurred in the cow-calf subsystem. This subsystem is encumbered with a high flow of inputs and emissions as it includes, besides cows, replacement heifers and calves up to 6.5 months old. The actual size of cull cow production, excluding calves, depends on the annual culling rate. Because the herd of suckler cows was kept stable (there was neither expansion nor extraction in numbers of cows) the culling rate was equal to the replacement rate. The low values of both factors therefore influenced the number of culling cows. The smallest quantities of inputs and GHG emissions were recorded in the subsystem of young bulls for slaughter. It can be assumed that a factor that induced a lower intensity of input consumption and lower emissions was mainly a shorter time of rearing in this group, compared to other ones, as well as the method of bull nutrition. Consumption of larger amounts of roughage by cattle is generally linked to a higher $\mathrm{CH}_{4}$ production on high-forage diet (Hegarty et al., 2007).

The total $\mathrm{CF}$ of the analyzed production system was $25.43 \mathrm{~kg} \mathrm{CO}$ eq. $\mathrm{kg}^{-1} \mathrm{LW}$ of cattle for sale (Table 3 ). The variation in the CF between subsystems of young cattle ranged from 9.3 to $14.4 \mathrm{~kg} \mathrm{CO}$ eq. $\mathrm{kg}^{-1} \mathrm{LW}$. The subsystem of cow-calf was marked by the 
highest value of CF. GHG emissions in this subsystem came from three different sources: calves up to 6.5 months, replacement heifers and cows. Identifying the aggregated emissions in this subsystem only with the culled cows, increases the CF by a lot. Thus, the $\mathrm{CF}$ in the basic breeding herd cannot be considered to be representative of the entire beef cattle production system.

Table 3. Carbon footprint (CF) breakdown for different subsystems of beef cattle production (per kg LW marketed beef cattle)

\begin{tabular}{|c|c|c|c|c|c|}
\hline Item & Cow-calf ${ }^{1}$ & $\begin{array}{l}\text { Breeding } \\
\text { heifer }\end{array}$ & $\begin{array}{l}\text { Breeding } \\
\text { bull }\end{array}$ & $\begin{array}{c}\text { Fattening } \\
\text { bull }\end{array}$ & $\begin{array}{l}\text { Whole } \\
\text { system }\end{array}$ \\
\hline Feeds: & 23.26 & 3.97 & 1.84 & 0.94 & 5.84 \\
\hline - Roughage, kg & 22.91 & 3.59 & 1.15 & 0.65 & 5.48 \\
\hline - Cereals, Concentrated feed & 0.35 & 0.38 & 0.69 & 0.29 & 0.36 \\
\hline Bedding & 0.71 & 0.13 & 0.10 & 0.12 & 0.23 \\
\hline Electricity, fuel & 2.26 & 0.36 & 0.32 & 0.29 & 0.66 \\
\hline Tractors and machines, $\mathrm{kg}$ & 0.22 & 0.04 & 0.03 & 0.04 & 0.07 \\
\hline Calves (0-6.5 m) & $\mathrm{n} / \mathrm{a}^{2}$ & n.i. ${ }^{3}$ & n.i. & n.i. & n.i. \\
\hline Emissions from animals and manure: & 64.35 & 9.91 & 8.94 & 7.88 & 18.63 \\
\hline - Entheric fermentation & 30.22 & 4.91 & 4.66 & 4.39 & 9.18 \\
\hline - Manure, g & 34.13 & 5.00 & 4.28 & 3.49 & 9.45 \\
\hline $\mathrm{CF}$ in total & 90.80 & 14.41 & 11.23 & 9.27 & 25.43 \\
\hline
\end{tabular}

Livestock in the subsystem of fattening bulls had the lowest value of CF. $85 \%$ of the $\mathrm{CF}$ was associated with biogenic emissions that have their source in enteric fermentation and manure management activity. The contribution of enteric fermentation to the $\mathrm{CF}$ was prevailing and exceeded manure emissions by nearly 10 percentage points. The share of feed represented only $10.1 \%$ of the total CF. Compared to the slaughtering bulls, the subsystem of breeding bulls had a higher CF by nearly $2 \mathrm{~kg} \mathrm{CO}_{2}$ eq. $\mathrm{kg}^{-1} \mathrm{LW}$. The results shown in Table 3 indicate that the key factors explaining differences in CF between the two subsystems were the upstream GHG emissions related to feed consumed, and the direct biogenic emissions. There were marked changes in the internal structure of the carbon footprint of the breeding bulls. Compared to the former subsystem, the proportion of emissions associated with feed production increased from $10.1 \%$ to $16.4 \%$, while the share of joint emissions from manure and enteric fermentation decreased from $85.0 \%$ to $79.6 \%$ of the overall value of CF. Another subsystem in which the CF of the products was higher than in the fattening bulls was breeding heifers. These heifers were characterized by a more than $55 \%$ higher CF compared to fattening bulls. When internal structure of the CF is considered against the background of the previous two subsystems, the further decrease of relative share of biogenic emissions to the level of $68.8 \%$ is observed. In absolute values, however, joint GHG emissions of manure and enteric fermentation here were the highest, over $9.9 \mathrm{~kg} \mathrm{CO}_{2}$ eq. $\mathrm{kg}^{-1} \mathrm{LW}$ of heifers for sale. Differences in the $\mathrm{CF}$ of the products between the analyzed subsystems were certainly the result of a combination of several essential factors. One of them was the time of rearing in a given subsystem and the body 
weight reached at sale. It can be noted that the CF increased as the time of cattle breeding was extended in the subsystem beef cattle production, from fattening bulls with the shortest breeding time, on average 14.5 months, to the subsystem of breeding heifers, with the longest breeding time of 21.5 months on average. In addition, breeding heifers at the time of sale reached lower final weight than fattening and breeding bulls. The type of feed used could also contribute to the diversification of the CF. In the feed ration of fattening bulls, besides the maize silage and concentrate mixtures, there also present byproduct feeds: silage of pressed beetroot pulp and wet distiller grain (data not presented). These feed products are classified as the wastes of the sugar and distilling industries, respectively. According to the LCA methodology, GHG emissions connected with processing operations in this type of industry are not attributed to the waste byproducts. They are allocated entirely to products with an unambiguous market value. For this reason, cattle feeding with waste byproducts did not constitute a significant source of GHG emissions (minor contributions to GHG emissions were involved with the processes of transport and preparation of silage). From the point of view of emission intensity, the use of this type of feed contributes significantly less to changes in the CF compared to other feeds.

When describing the CF of the cow-calf subsystem, one has to be aware that the main purpose of this subsystem is to supply young calves for further production. Considering this in this context, culled cows are then seen as the second co-product. According to the LCA methodology, GHG emissions were allocated between these co-products in the following proportion 0.789:0.121 (Table 4). The basis for the adoption of specific CF allocation coefficients was the estimation of the annual energy demand of cows and other cattle in this subsystem, as well as data on the quantity of products leaving this subsystem (IPCC 2006). After allocating GHG emissions, the CF of $1 \mathrm{~kg} \mathrm{LW}$ of culled cow was $11.0 \mathrm{~kg} \mathrm{CO}_{2}$ eq. compared to $90.8 \mathrm{~kg} \mathrm{CO}_{2}$ eq. before allocation. On the other hand, an after-effect of allocation was that more GHG emissions were shifted to calves. Calves, at weaning from the suckler cow, carried an emission burden of this subsystem equal to $50.6 \mathrm{~kg} \mathrm{CO}_{2}$ eq. $\mathrm{kg}^{-1} \mathrm{LW}$.

Table 4. Overview of allocation of greenhouse gases to co-products within cow-calf beef production subsystem

\begin{tabular}{l|cc}
\hline \multicolumn{1}{c|}{ Specification } & Cow & Calves (0-6.5 months) \\
\hline GWP of the cow-calf ${ }^{1}$ subsystem, & & \\
kg CO $_{2}$ eq. per year & & 9869.9 \\
Allocation, \% & 0.121 & 0.879 \\
No of animals leaving subsystem & 0.164 & 0.879 \\
Live weight of animals, kg & 663.0 & 217.9 \\
Quantity of products, kg & 108.7 & 171.3 \\
GWP per kg LW & $11.0^{2}$ & 50.6
\end{tabular}

${ }^{1}$ data for one unit of basic breeding herd composed of 1 cow, 0.164 replacement heifer and 0.95 calves produced per year, ${ }^{2}$ culled cow, ${ }^{3}$ weaned calves

Source: Authors' own calculations.

Figure 2. presents the $\mathrm{CF}$ of the products for subsystems of beef cattle production in the life-cycle from birth to sale. By including GHG emissions related within the first life stage of calves (period from birth to weaning), this resulted in a surge of CF for all subsystems of cattle breeding. In the subsystem of fattening bulls ( $0-21$ months), the CF increased to $25.4 \mathrm{~kg} \mathrm{CO}$ eq. $\mathrm{kg}^{-1} \mathrm{LW}$ from $9.27 \mathrm{~kg} \mathrm{CO}$ eq. $\mathrm{kg}^{-1} \mathrm{LW}$. 


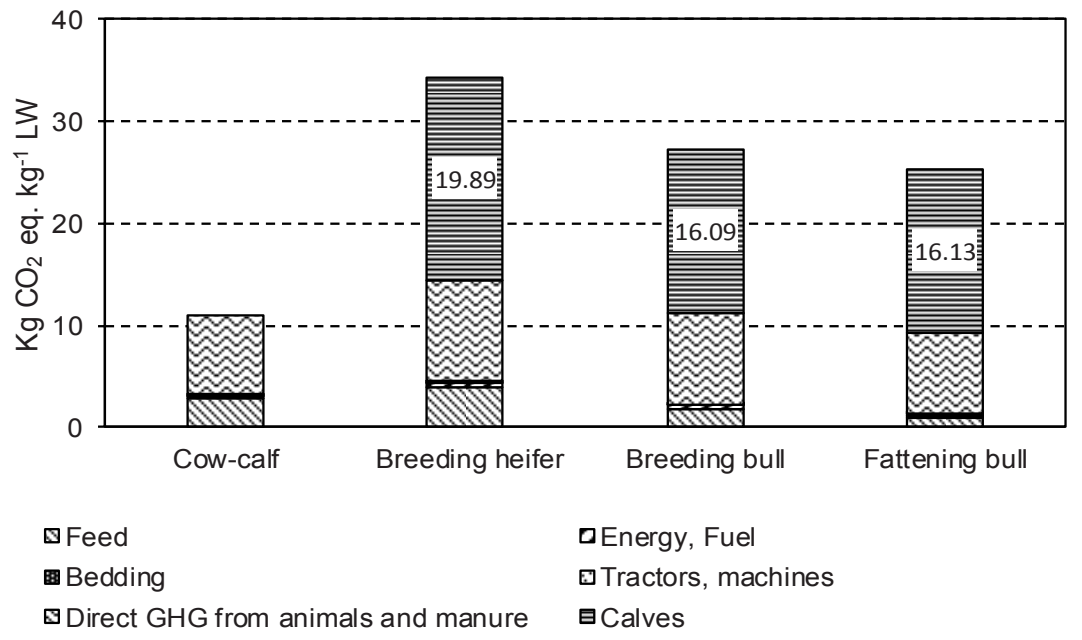

Fig. 2. Carbon footprint breakdown with additional input included from calves (0-6.5 months) to GHG emissions for different subsystems of beef cattle production

Source: Authors' own calculations.

The range of increase of the CF was equally high in the breeding bulls' subsystem. The total $\mathrm{CF}$ has increased to $27.32 \mathrm{~kg} \mathrm{CO}_{2} \mathrm{~kg}^{-1} \mathrm{LW}$. The $\mathrm{CF}$ of young beef cattle grazed on pastures and fed with hay during the winter in the Upper Midwest (USA) was $14.8 \mathrm{~kg} \mathrm{CO}_{2}$ eq. $\mathrm{kg}^{-1}$ LW (Pelletier et al. 2010). In Ireland, when beef cattle feeding was based on the composition of grass, forage and concentrate feed, GHG emission of $11.26 \mathrm{~kg} \mathrm{CO}_{2}$ eq. $\mathrm{kg}^{-1}$ LW was obtained (Casey and Holden, 2006). In Italy, where a system of intensive cattle production consisted of cow-calf and fattened animals to the weight $650-700 \mathrm{~kg}$, kept in confinement, the GHG emissions per kg of livestock was $17.62 \mathrm{~kg} \mathrm{CO}_{2}$ eq.

Under the extensive conditions of cattle production, where cows were kept in the pasture all year long and calves to weaning (aged 6-7 months), the CF of livestock was higher and amounted to $26.30 \mathrm{~kg} \mathrm{CO}_{2}$ eq. $\mathrm{kg}^{-1} \mathrm{LW}$ (Bragaglio et al., 2018). In France, GHG emissions in the beef cattle system relying on the Charolaise beef breed were in the range of 15.3-15.9 kg CO 2 eq. $\mathrm{kg}^{-1}$ LW (Nguyen et al. 2012). Differences in GHG emissions between beef cattle systems were explained by those authors due to higher productivity of an intensive system while at the same time reducing $\mathrm{CH}_{4}$ emissions due to the smaller share of roughage in the diet. It is noted that there is a high variability in the results of research on beef cattle CF due to methodological differences of LCA analyses (e.g. allocation rules, system boundaries, adopted emission assessment models, type of functional units and technological differences between production systems (Desjardins et al. 2012). Breeding heifers (0-28 months) had the highest $\mathrm{CF}$, reaching a value of $34.3 \mathrm{~kg} \mathrm{CO}_{2}$ eq. $\mathrm{kg}^{-1} \mathrm{LW}$. The majority of GHG emissions in this subsystem was contributed by calves (0-6.5 months). GHG emissions from this source represented close to $60 \%$ of the total CF. Results show that calves weaned from suckler cows that enter subsequent production subsystems are the most important source of indirect GHG emissions. As shown, the CF of the end products by whole chain approach thus covers all GHG emissions from animal birth to farm gate. This approach is in line with the principles of the LCA methodology which 
recommends analysis of environmental impacts related to animal production processes in their full life cycle.

\section{Conclusions}

The average value of the $\mathrm{CF}$ across the entire beef cattle production system, with aggregated inputs and emissions in all subsystems, was $25.43 \mathrm{~kg} \mathrm{CO}_{2}$ eq. per $\mathrm{kg} \mathrm{LW}$ of marketed animals. The diverse nature of the products obtained (in terms of quality, type and direction of use) necessitates the analysis of the CF in each subsystem individually. According to the LCA methodology, the analysis of environmental effects should be done for all final products within the analyzed system. An important step in the analysis of the CF was the attribution of the GHG emissions associated with the production of calves in the cow-calf subsystem (i.e. basic breeding herd) to different cattle livestock subsystems. It turned out that the GHG emissions that originated in the first phase of beef cattle life, identified with calves' life from birth to weaning, have a greater impact on the final value of the CF than the emission load from the second phase of life, i.e. after weaning until the sale of cattle. In the subsystem of fattening bulls, the CF per kg LW of marketed bulls, which involved altogether contribution from the cow-calf subsystem and a contribution from the fattening period (i.e. production period 0-21 months), increased close to three folds compared to the CF that involved only the fattening period (6.5-21 months) and was equal to $25.40 \mathrm{~kg} \mathrm{CO}_{2}$ eq.

The determination of $\mathrm{CF}$ is an important complement to the environmental characteristics of the beef cattle production. The diversity of production systems, their different intensity and the use of many breeds of beef cattle with specific genetic conditions and different nutritional requirements necessitates the extensive CF analyses across a broad range of conditions. Poland's breeding of beef cattle has been on the path of systematic development for a dozen years. A much larger part of its production is exported to other countries. In Western societies with increasing ecological sensitivity, having information about the CF and the other environmental effects of products may become for them an important element of purchasing decisions, which should be regarded as an opportunity to gain better access for beef meat to competitive markets in the world. The reported results of CF can become a baseline for other beef cattle production systems. They can be treated as reference values in comparative studies on new technologies and strategies of beef cattle breeding in Poland, whose aim is to reduce the warming potential of beef cattle production and thereby mitigate the effects of climate change.

The CF of beef cattle was estimated based on the life cycle analysis, including the preproduction phase, consisting of the acquisition of raw materials and their processing, and the production phase on the farm. The boundaries of the analysis allowed to estimate the GHG emissions accompanying the complex of processes in the production chain at stages from "cradle-to-farm-gate". Inventory of inputs and emissions in the production system of beef cattle, together with the assessed CF's, could be a valuable source of entry data for the slaughter and meat processing industry after it decides to disseminate estimates of the CF of the meat processed products. 


\section{Literature}

Bieńkowski, J., Holka, M., Jankowiak, J. (2017). Assessing the greenhouse gas emissions by carbon footprint in intensive agricultural production based on the examples of winter oilseed rape. Problems of World Agriculture 17, 18-28 (In Polish with English abstract).

Bragaglio, A., Napolitano, F., Pacelli, C., Pirlo, G., Sabia, E., Serrapica, F., Serrapica, F., Braghieri, A. (2018). Environmental impacts of Italian beef production: a comparison between different systems. Journal of Cleaner Production 172, 4033-4043.

BSI (2011). PAS 2050:2011. Specification for the assessment of the life cycle greenhouse gas emissions of goods and services. British Standards Institute, London, UK.

Casey, J.W., Holden, N.M. (2006). Quantification of GHG emissions from sucker-beef production in Ireland. Agricultural Systems 90, 79-98.

Desjardins, R.L., Worth, D.E., Vergé, X.P.C., Maxime, D., Dyer, J., Cerkowniak, D. (2012). Carbon footprint of beef cattle. Sustainability 4, 3279-3301.

Ecoinvent database v. 3.5. 2018. Swiss Centre for Life Cycle Inventories.

EEA (2013). EMEP/EEA air pollutant emission inventory guidebook 2013. European Environment Agency, Luxembourg.

EPD (2018). The International EPD System. EPD International AB. Available 20 February 2018 from: https://www.environdec.com.

FAOSTAT (2018). Food and Agriculture Organization of the United Nations, Crops and livestock products. Available 20 February 2018 from: http: www.fao.org/faostat/en/\#data/TP.

Gerber, PJ, Steinfeld, H, Henderson, B, Mottet, A, Opio, C, Dijkman, J, Falcucci, A, Tempio, G (2013). Tackling climate change through livestock - A global assessment of emissions and mitigation opportunities. FAO, Rome.

GUS (2017). Ochrona środowiska 2017 (Environment 2017). Główny Urząd Statystyczny, Warszawa.

GUS (2018). Bank danych lokalnych. Available 20 February 2018 from: https://bdl.stat.gov.pl/BDL/dane/ podgrup/tablica.

Hegarty, R., Goopy, J., Herd, R., McCorkell, B. (2007). Cattle selected for lower residual feed intake have reduced daily methane production. Journal of Animal Science 85, 1479-1486.

Holka, M., Jankowiak, J., Bieńkowski, J., Dabrowicz, R. (2016). Life cycle assessment (LCA) of winter wheat in an intensive crop production system in Wielkopolska region (Poland). Applied Ecology and Environmental Research 14, 535-545.

Huijbregts, M., Hellweg, S., Frischknecht, R., Hendriks, H., Hungerbuler, K., Henriks, J. (2010). Cumulative energy demand as predictor for the environmental burden of commodity production. Environmental Science and Technology 44, 2189-2196.

IPCC (2006). 2006 IPCC Guidelines for national greenhouse gas inventories. IPCC National Greenhouse Gas Inventories Programme, Technical Support Unit, Institute for Global Environmental Strategies, Hayama, Kanagawa, Japan.

ISO (2013). ISO/TS 14067:2013. Greenhouse gases - Carbon footprint of products - Requirements and guidelines for quantification and communication. International Organization for Standardization, Geneva.

Marinussen, M., van Kernebeek, H., Broekema, R., Groen, E., Kool, A., van Zeist, W.J., Dolman, M., Blonk, H (2012a). LCI data for the calculation tool Feedprint for greenhouse gas emissions of feed production and utilization. Cultivation oil seeds and oil fruits. Blonk Consultants, Wageningen University and Research Centre.

Marinussen, M., van Kernebeek, H., Broekema, R., Groen, E., Kool, A., van Zeist, W.J., Dolman, M., Blonk, H. (2012b). LCI data for the calculation tool Feedprint for greenhouse gas emissions of feed production and utilization. Cultivation cereal grains. Blonk Consultants, Wageningen University and Research Centre.

Nguyen, T.L.T., Hermansen, J.E., Mogensen, L. (2010). Environmental consequences of different beef production systems in the EU. Journal of Cleaner Production 18, 756-766.

Nguyen, T.T.H., van der Werf, H.M.G., Eugène, M., Veysset, P., Devun, J., Chesneau, G., Doreau, M. (2012) Effects of type of ration and allocation methods on the environmental impacts of beef-production systems. Livestock Science 145, 239-251.

Pelletier, N., Pirog, R., Rasmussen, R. (2010). Comparative life cycle environmental impacts of three beef production strategies in the Upper Midwestern United States. Agricultural Systems 103, 380-389.

Polish Beef Association (2018). QMP system. Polskie Zrzeszenie Producentów Bydła Mięsnego. Available 20 February 2018 from: http://www.pzpbm.pl/node/161?language=en.

PRé Consultants (2018). SimaPro 8.5 Pro. LCA software. Amersfoort, The Netherlands. 
Regulation (EU) No 1308/2013 of the European Parliament and of the Council of 17 December 2013. Official Journal of the European Union L347, 20.12.2013, 671-854

Steinfeld, H., Gerber, P., Wassenaar, T., Castel V., Rosales M., Haan C. (2006). Livestock's long shadow: environmental issues and options. FAO, Rome.

Vergé, X.P.C., De Kimpe, C., Desjardins, R.L. (2007). Agricultural production, greenhouse gas emissions and mitigation potential. Agricultural and Forest Meteorology 142, 255-269.

Wiedmann, T., Minx, J. (2007). A definition of 'Carbon Footprint'. ISA Research and Consulting, Durham, UK.

\section{For citation:}

Bieńkowski J., Holka M., Dąbrowicz R., Jankowiak J. (2018). Carbon Footprint of Beef Cattle in a Conventional Production System: a Case Study of a Large-Area Farming Enterprise in the Wielkopolska Region. Problems of World Agriculture, 18(3), 23-35;

DOI: 10.22630/PRS.2018.18.3.63 